\title{
Prevalence of anogenital infection by Human Papillomavirus (HPV) in users of
}

\section{immunobiological therapy}

\author{
Prevalência da infecção anogenital pelo Papilomavírus Humano (HPV) em usuários de terapia \\ imunobiológica \\ Prevalencia de infección anogenital por Virus del Papiloma Humano (VPH) en usuarios de terapia \\ inmunobiológica
}

Received: 02/01/2022 | Reviewed: 02/12/2022 | Accept: 02/16/2022 | Published: 02/23/2022

\author{
Eduardo Vinícius Mendes Roncada \\ ORCID: https://orcid.org/0000-0002-2149-2388 \\ Hospital Regional de Presidente Prudente, Brazil \\ Universidade do Oeste Paulista, Brazil \\ E-mail: eduardoroncada.dermatologia@hotmail.com \\ Murilo de Oliveira Lima Carapeba \\ ORCID: https://orcid.org/0000-0002-0817-932X \\ Hospital Regional de Presidente Prudente, Brazil \\ Universidade do Oeste Paulista, Brazil \\ E-mail: murilolima@gmail.com \\ José Eduardo Levi \\ ORCID: https://orcid.org/0000-0002-3557-2717 \\ DASA Group, Brazil \\ E-mail: dudilevi@usp.br \\ Marilda Aparecida Milanez Morgado de Abreu \\ ORCID: https://orcid.org/0000-0001-9099-6013 \\ Hospital Regional de Presidente Prudente, Brazil \\ Universidade do Oeste Paulista, Brazil \\ E-mail: marilda@morgadoeabreu.com.br
}

\begin{abstract}
Objective: To compare the prevalence of anogenital infection by human papillomavirus (HPV) in immunobiological users being treated for immune-mediated chronic inflammatory diseases with that in non-users. Methodology: The total sample studied consisted of 228 participants divided into 2 groups: 114 users and 114 non-users of immunobiological, cytotoxic or corticosteroid therapy, with non-psoriasis dermatoses and non-HPV predisposing conditions. Both groups were evaluated clinically and by polymerase chain reaction (PCR). Results: The prevalence of low-risk HPV in the immunobiological user and non-user groups was 8/49 (16,3\%) and 3/29 (10,3\%), respectively $(\mathrm{p}=0.524)$. The low-risk types found were HPV 6, 11, 40, 42 and 44. The prevalence of high-risk HPV was 23/114 $(20,2 \%)$ in the users versus $21 / 114(18,4 \%)$ in the non-users $(\mathrm{p}=0.737)$, distributed according to the following types: HPV $16(3 / 228-1,3 \%), 18(5 / 228-2,2 \%)$, and non-16/18 (36/228 - 15,8\%). After pairing by sex and age, the prevalence of high-risk HPV was 13/62 (21,0\%) and 8/62 (12,9\%) for immunobiological users and non-users, respectively $(\mathrm{p}=0.231)$. Conclusion: The prevalence of anogenital HPV infection in patients with immune-mediated chronic inflammatory diseases treated with immunobiologicals is similar to that in non-users.

Keywords: Monoclonal antibodies; Condyloma acuminate; Inflammation; Sexually transmitted viral diseases; Immunosuppressants.
\end{abstract}

\section{Resumo}

Objetivo: Comparar a prevalência de infecção anogenital pelo papilomavírus humano (HPV) em pacientes em tratamento para doenças inflamatórias crônicas imunomediadas tratadas ou não com imunobiológicos. Metodologia: A amostra total estudada foi de 228 participantes divididos em 2 grupos: 114 usuários e 114 não usuários de terapia imunobiológica, citotóxica ou corticosteróides, com dermatoses não psoriáse e sem condições predisponentes para o HPV. Ambos os grupos foram avaliados clinicamente e por reação em cadeia da polimerase (PCR). Resultados: A prevalência de HPV de baixo risco nos grupos de usuários e não usuários de imunobiológicos foi de 8/49 (16,3\%) e $3 / 29(10,3 \%)$, respectivamente $(\mathrm{p}=0,524)$. Os tipos de baixo risco encontrados foram HPV 6, 11, 40, 42 e 44. A prevalência de HPV de alto risco foi de 23/114 (20,2\%) nos usuários versus 21/114 (18,4\%) nas não usuárias ( $\mathrm{p}=0,737)$, distribuída de acordo com os seguintes tipos: HPV $16(3 / 228-1,3 \%), 18(5 / 228$ - 2,2\%) e não-16/18 (36/228 - 15,8\%). Após o pareamento por sexo e idade, a prevalência de HPV de alto risco foi de 13/62 (21,0\%) e 8/62 (12,9\%) para usuários e não usuários de imunobiológicos, respectivamente ( $\mathrm{p}=0,231)$. Conclusão: A prevalência 
de infecção anogenital por HPV em pacientes com doenças inflamatórias crônicas imunomediadas tratadas com imunobiológicos é semelhante à de pacientes não usuários desta terapia.

Palavras-chave: Anticorpos monoclonais; Condiloma acuminado; Inflamação; Doenças virais sexualmente transmissíveis; Imunossupressores.

\begin{abstract}
Resumen
Objetivo: Comparar la prevalencia de infección anogenital a raíz del virus del papiloma humano (VPH) en personas que toman fármacos inmunobiológicos en tratamiento por enfermedades inflamatorias crónicas inmunomediadas con dicha prevalencia en quienes no los utilizan. Metodología: La muestra total estudiada estuvo compuesta por 228 participantes divididos en 2 grupos: 114 usuarios y 114 no usuarios de terapia inmunobiológica, citotóxica o corticosteroide, con dermatosis no psoriásicas y sin condiciones predisponentes para VPH. Ambos grupos fueron evaluados clínicamente y por reacción en cadena de la polimerasa (PCR). Resultados: Los valores de prevalencia de VPH de bajo riesgo en personas que toman fármacos inmunobiológicos y en grupos de individuos que no los utilizan fueron $8 / 49(16,3 \%)$ y $3 / 29(10,3 \%)$, respectivamente $(\mathrm{p}=0.524)$. Los tipos de bajo riesgo que se encontraron fueron VPH 6, 11, 40, 42 y 44. La prevalencia de VPH de alto riesgo fue 23/114 (20,2\%) en quienes toman fármacos inmunobiológicos, en comparación con 21/114 (18,4\%) entre quienes no los utilizan ( $\mathrm{p}=0.737)$, distribuida conforme a los siguientes tipos: VPH 16 (3/228 - 1,3\%), VPH 18 (5/228 - 2,2\%) y VPH no 16/18 (36/228 - 15,8\%). Después de emparejar por sexo y edad, los valores de prevalencia de VPH de alto riesgo fueron 13/62 (21,0\%) y 8/62 (12,9\%) para personas que toman fármacos inmunobiológicos y para quienes no los utilizan, respectivamente $(\mathrm{p}=0.231)$. Conclusión: La prevalencia de infección anogenital por VPH en pacientes con enfermedades inflamatorias crónicas inmunomediadas tratados con fármacos inmunobiológicos es similar a la de quienes no utilizan dichos medicamentos.

Palabras clave: Anticuerpos monoclonales; Condiloma acuminado; Inflamación; Enfermedades virales de transmisión sexual; Inmunosupresores.
\end{abstract}

\title{
1. Introduction
}

Anogenital infection with human papillomavirus (HPV) is the most common sexually transmitted viral disease in the world. According to the World Health Organization, approximately 630 million people (1:10 people) are infected with HPV, and approximately $70 \%$ of the sexually active population will be infected. The highest incidence is among young people, with a peak from 20 to 24 years old, and an incidence reaching $46 \%$ in the uterine cervix in the group ranging from 20 to 30 years old. Clinically apparent perigenital and perianal warts, occur in $1 \%$ of infected people and can be recurrent or persistent. In contrast, subclinical or latent infections are asymptomatic. A diagnosis can be made by molecular techniques, such as polymerase chain reaction (PCR), identifying viral DNA and the virus type (Colpani et al., 2020; Fedrizzi, 2011; Forman et al., 2012; Lacey, 2019; Oliveira et al., 2013; Sanjosé et al., 2018; Serrano et al., 2018).

Immunobiological therapy is widely used to treat immune-mediated chronic inflammatory diseases. Among the immunobiologicals used, there are three agents that inhibit tumour necrosis factor-alpha (anti-TNF- $\alpha$ ), infliximab, etanercept and adalimumab, and two anti-interleukin (anti-IL) monoclonal antibodies, ustekinumab (anti-IL 12/23) and secukinumab (anti-IL 17A). However, the immunosuppression resulting increases the risks of infections and neoplasms. Therefore, before starting immunobiological, an epidemiological survey and laboratory and imaging tests are recommended (Colpani et al., 2020; Galloway et al., 2011; Lacey, 2019; Mota et al., 2015; Oliveira et al., 2013; Sanjosé et al., 2018; Serrano et al., 2018).

The most prevalent sites of infection associated with immunobiologicals are upper respiratory tract, followed by cutaneous and soft tissue and urinary tract. The most concerning infection are tuberculosis, hepatitis B and C, syphilis and human immunodeficiency virus (HIV). If any of these diseases is detected, they must be treated before starting immunobiological therapy (Dixon et al., 2010; Galloway et al., 2011; Mota et al., 2015; Singh et al., 2011).

Seventy per cent of carcinomas of the cervix and up to $90 \%$ of anorectal and oropharynx cancers are caused by HPV 16 or 18. Screening for cervical cancer consists of gynaecological examination using oncotic cytology, which has low sensitivity. A meta-analysis found a prevalence rate of $14.4 \%$ for HPV infection detected by PCR in a population in which cytology or clinical examination was negative (Bao et al., 2008; Colpani et al., 2020; Dommasch et al., 2011; Fedrizzi, 2011; Lacey, 2019; Sanjosé et al., 2018; Serrano et al., 2018). 
This study draws attention to HPV, for which screening prior to immunobiological prescription is not common. Some reports on anogenital warts caused by HPV, in the presence of immunobiologicals, are published in the literature, but the data are insufficient and contradictory (Antoniou et al., 2008; Kim \& Solomom, 2010). The aim of this study was to determine the prevalence of anogenital HPV infection between patients with chronic immune-mediated inflammatory diseases treated with immunobiologicals.

\section{Methodology}

This is a cross-sectional observational study, developed at the Regional Hospital in Presidente Prudente, SP. Patients were investigated simultaneously and consecutively, as they attended appointments. The data collection occurred from February 2019 to March 2020. Two groups were included:

User group: patients with chronic immune-mediated inflammatory disease being treated with immunobiologicals.

Non-user group: patients without chronic immune-mediated inflammatory disease who were not being treated with immunobiologicals.

The study was approved by the Research Ethics Committee of Universidade do Oeste Paulista (CAAE: 81833317.4.00005515). All participants signed a consent form.

\section{Inclusion criteria:}

Patients of both sexes, over 18 years old:

User group: using an anti-TNF- $\alpha$ or anti-IL agent to treat chronic immune-mediated inflammatory diseases;

Non-user group: without chronic immune-mediated inflammatory disease, not using immunosuppressants and without signs or symptoms of conditions leading to immunosuppression (neoplasms, diabetes mellitus, haematological diseases, hepatitis B or C, seropositivity for HIV and organ transplant).

\section{Exclusion criteria:}

User group: patients who interrupted their treatment with immunobiologicals for a period longer than five half-lives of the drug.

Non-user group: patients using immunosuppressive drugs or with any immunosuppressive condition.

Sample size: Assuming that the prevalence of HPV in immunobiologicals non-users was approximately $10 \%$, similar to the lowest rates in the general population (Fedrizzi, 2011; Oliveira et al., 2013; Parkin et al., 2005), and estimating that the prevalence in users was $25 \%$, a $15 \%$ difference between the groups ( $25 \%$ vs. $10 \%$ ), with $5 \%$ type I error and $80 \%$ statistical power, was used for the sample size calculation, and 100 patients for each group was calculated. A further 14 patients were added to each group, adding up to 114 patients per group.

Sociodemographic and anamnesis data: Information on sex, age, skin colour, age of first sexual intercourse, number of partners, previous vaccination for HPV, and history of anogenital viral warts (active or past) was collected. For the user group, data related to the immunobiological (name, time of use, dose, route of application and indication), previous use of another immunobiological, presence of comorbidities, and simultaneous use of other immunosuppressive drugs were also collected.

Physical examination data and material collection: anogenital examination, and when warts present, the number and location were recorded. The 5\% acetic acid test was performed to view small or subclinical warts (Fedrizzi, 2011; Forman et al., 2012). Next, mucocutaneous material was collected with a cytological brush (Abbott Cervi Collect ${ }^{\circledR}$, Des Plaines, IL, USA). The swab was rubbed with circular movements. In men, the sequence was urethral ostium, glans, balano-preputial 
furrow and anal region; in women, the sequence was labia majora and minora, urethral ostium, vaginal opening and anal area. The material was placed in a sterile flask containing $2.5 \mathrm{ml}$ of a preservative solution composed of guanidine thiocyanate in Tris buffer. The samples were sent to the Molecular Biology sector of Dasa Laboratory (Barueri-SP), where they were kept at room temperature from $15^{\circ} \mathrm{C}$ to $30^{\circ} \mathrm{C}$ and processed within 6 weeks.

Molecular examination: For PCR, the Abbott Real Time High Risk HPV automated test (Abbott Laboratories, Des Plaines, IL, USA) was used. Samples were submitted in batches of 94 samples and 2 controls (positive and negative) for DNA extraction. Primers, called High-Risk-HPV, were used to amplified a fragment of the L1 gene of HPV types with a high oncogenic risk (types 16 and 18 were separate, while types 31/33/35/39/45/51/52/56/58/59/66/68 were grouped in a single probe). The mixture also contained primers and a probe for the endogenous beta-globin gene. All participants were tested for positivity for high-risk HPV DNA and classified into 4 categories: HPV 16, HPV 18, both HPV 16 and 18 and HPV non16/18. Some samples were randomly screened for low-oncogenic risk HPV. Therefore, primer and probe sequences from Integrated DNA Technologies (Coralville, Iowa, USA) were used to amplify the low-oncogenic HPV L1 gene fragment, allowing the detection and typing of the following genotypes: HPV 6/11/40/42/43/44.

Statistical analysis: Considering the sociodemographic and clinical aspects of the participants, for qualitative variables, the absolute and relative frequencies were calculated. For quantitative variables, the average, median, standard deviation (SD) and minimum and maximum values were calculated. The associations between qualitative variables were assessed using Pearson's chi-square test or Fisher's exact test. The Kolmogorov-Smirnov test did not show normality, so comparisons of quantitative variables between groups were performed using the Mann-Whitney test. The propensity score matching (PSM) method was used to control the effects of confounding variables in relation to the immunobiological user and non-user groups. The odds ratio measure was calculated using logistic regression with a 95\% confidence interval $(95 \% \mathrm{CI})$. The level of significance adopted was $5 \%$. Analyses were performed using IBM ${ }^{\circledR}$ SPSS Statistics 25.

\section{Results}

\section{Sociodemographic, anamnesis and physical examination data}

Men represented $56.1 \%$ of the patients among immunobiologicals users, while $63.2 \%$ of non-users were women $(\mathrm{p}=0.003)$. Among users, the patients were, on average, 50 years old ( $\mathrm{SD}=13.6$ years), while non-users were 44.3 years old $[\mathrm{SD}=14.3$ years $(\mathrm{p}=0.004)]$. A higher number of black patients were included in the user group $(\mathrm{p}=0.025)$. Additionally, among users, $13.2 \%$ reported previous warts, while only $5.3 \%$ of non-users $\operatorname{did}(\mathrm{p}=0.039)$. Other factors analysed were not statistically associated with the use or non-use of an immunobiological (Table 1). 
Table 1. Sociodemographic characteristics, anamnesis data and physical examination of the study participants, according to the use or non-use of immunobiologicals. Presidente Prudente, SP, 2020.

\begin{tabular}{|c|c|c|c|c|}
\hline \multirow[b]{2}{*}{ Characteristics } & \multicolumn{2}{|c|}{ Use of immunobiologicals } & \multirow[b]{2}{*}{$\begin{array}{c}\text { Total } \\
\text { n = 228 } \\
\text { n }(\%)\end{array}$} & \multirow[b]{2}{*}{$P$ value } \\
\hline & $\begin{array}{c}\text { No } \\
\mathrm{n}=114 \\
\mathrm{n}(\%)\end{array}$ & $\begin{array}{c}\text { Yes } \\
\text { n }=114 \\
\text { n }(\%)\end{array}$ & & \\
\hline Gender & & & & $0,003^{1}$ \\
\hline Male & $42(36,8)$ & $64(56,1)$ & $106(46,5)$ & \\
\hline Female & $72(63,2)$ & $50(43,9)$ & $122(53,5)$ & \\
\hline Age & & & & $0,004^{3}$ \\
\hline Average (SD) & $44,3(14,3)$ & $50,0(13,6)$ & $47,2(14,2)$ & \\
\hline Median (min-max) & $44(18-78)$ & $52(22-82)$ & $48(18-82)$ & \\
\hline 18 to 30 years & $27(23,7)$ & $13(11,4)$ & $40(17,5)$ & $0,026^{1}$ \\
\hline 31 to 50 years & $46(40,4)$ & $41(36,0)$ & $87(38,2)$ & \\
\hline 51 to 70 years & $38(33,3)$ & $53(46,5)$ & $91(39,9)$ & \\
\hline$>70$ years & $3(2,6)$ & $7(6,1)$ & $10(4,4)$ & \\
\hline \multicolumn{5}{|l|}{ Skin colour } \\
\hline White & $85(74,6)$ & $71(62,3)$ & $155(68,3)$ & \\
\hline Brown & $23(20,2)$ & $23(20,2)$ & $46(20,3)$ & \\
\hline Black & $5(4,4)$ & $14(12,2)$ & $19(8,4)$ & $0,025^{2}$ \\
\hline Yellow & $1(0,9)$ & $6(5,3)$ & $7(3,1)$ & \\
\hline Active wart & & & & $0,811^{1}$ \\
\hline No & $104(91,2)$ & $105(92,1)$ & $209(91,7)$ & \\
\hline Yes & $10(8,8)$ & $9(7,9)$ & $19(8,3)$ & \\
\hline Number of warts & & & & $0,847^{2}$ \\
\hline Zero lesion & $104(91,2)$ & $105(92,1)$ & $209(91,7)$ & \\
\hline 1-4 lesion & $9(7,9)$ & $7(6,1)$ & $16(7,0)$ & \\
\hline 5-10 lesion & $1(0,9)$ & $2(1,8)$ & $3(1,3)$ & \\
\hline Wart location & & & & $0,582^{2}$ \\
\hline Genital & $9(90,0)$ & $7(77,8)$ & $16(84,2)$ & \\
\hline Anal & $1(10,0)$ & 0 & $1(5,3)$ & \\
\hline Other location & 0 & $1(11,1)$ & $1(5,3)$ & \\
\hline Genital + urethral + anal & 0 & $1(11,1)$ & $1(5,3)$ & \\
\hline Age of $1^{\text {st }}$ sexual intercourse & & & & $0,570^{3}$ \\
\hline Average (SD) & $17,0(3,1)$ & $17,1(3,2)$ & $17,0(3,1)$ & \\
\hline Median (min-max) & $16(12-28)$ & $17(12-28)$ & $17(12-28)$ & \\
\hline Number of partners & & & & $0,104^{1}$ \\
\hline 1 partner & $29(25,4)$ & $38(33,3)$ & $67(29,4)$ & \\
\hline 2 partners & $19(16,7)$ & $15(13,2)$ & $34(14,9)$ & \\
\hline 3 partners & $20(17,5)$ & $9(7,9)$ & $29(12,7)$ & \\
\hline 4 partners & $7(6,1)$ & $6(5,3)$ & $13(5,7)$ & \\
\hline 5 partners & $7(6,1)$ & $3(2,6)$ & $10(4,4)$ & \\
\hline$>5$ partners & $32(28,1)$ & $43(37,7)$ & $75(32,9)$ & \\
\hline Vaccinated for $H P V$ & & & & NA \\
\hline No & $114(100)$ & $114(100)$ & $228(100)$ & \\
\hline Personal history of wart & & & & $0,039^{1}$ \\
\hline No & $108(94,7)$ & $99(86,8)$ & $207(90,8)$ & \\
\hline Yes & $6(5,3)$ & $15(13,2)$ & $21(9,2)$ & \\
\hline Acetic acid test positivity & & & & \\
\hline No & $114(100)$ & $103(90,4)$ & $217(95,2)$ & $0,001^{2}$ \\
\hline Yes & 0 & $11(9,6)$ & $11(4,8)$ & \\
\hline
\end{tabular}

SD: standard deviation; min: minimum value; max: maximum value; NA: not available. 1 Pearson's chi-square test; 2 Fisher's exact test; 3 Mann-Whitney test. Source: Own elaboration.

The characteristics of patients in the group of immunobiological users are shown in Table 2 . 
Table 2. Factors of patients in the group using immunobiologicals. Presidente Prudente, SP, 2020.

\begin{tabular}{|c|c|c|c|}
\hline Factors & & & $\begin{array}{c}\mathrm{n}=114 \\
\mathrm{n}(\%)\end{array}$ \\
\hline \multirow[t]{5}{*}{ Biological medicine } & Infliximab & & $4(3,5)$ \\
\hline & Etanercept & & $4(3,5)$ \\
\hline & Adalimumab & & $47(41,2)$ \\
\hline & Ustekinumab & & $24(21,1)$ \\
\hline & Secukinumab & & $35(30,7)$ \\
\hline \multirow[t]{2}{*}{ Time of use of biological medication (months) } & Average (SD) & $16,3(21,1)$ & \\
\hline & Median (min-max) & $7(1-120)$ & \\
\hline \multirow[t]{7}{*}{ Indication of biological medicine } & Psoriasis only & & $57(50,0)$ \\
\hline & RA only & & $6(5,3)$ \\
\hline & EA & & $3(2,6)$ \\
\hline & Crohn only & & $3(2,6)$ \\
\hline & Hidradenitis Suppurativa & & $9(7,9)$ \\
\hline & Psoriasis + A. PSO & & $35(30,7)$ \\
\hline & RA + Crohn & & $1(0,9)$ \\
\hline \multirow[t]{2}{*}{ Previous use of another biological medicine } & No & & $86(75,4)$ \\
\hline & Yes & & $28(24,6)$ \\
\hline \multirow[t]{7}{*}{ Use of other immunosuppressants } & None & & $81(71,1)$ \\
\hline & Prednisone & & $4(3,5)$ \\
\hline & Methotrexate & & $19(16,7)$ \\
\hline & Cyclosporine & & $2(1,8)$ \\
\hline & Azathioprine & & $1(0,9)$ \\
\hline & Another immunosuppressant & & $4(3,5)$ \\
\hline & Prednisone + methotrexate & & $3(2,6)$ \\
\hline \multirow[t]{10}{*}{ Presence of comorbidities } & None & & $71(62,3)$ \\
\hline & STI & & $12(10,5)$ \\
\hline & Hepatitis B & & $1(0,9)$ \\
\hline & DM & & $5(4,4)$ \\
\hline & Hematological & & $2(1,8)$ \\
\hline & Another disease & & $15(13,2)$ \\
\hline & $\mathrm{STI}+\mathrm{DM}$ & & $1(0,9)$ \\
\hline & STI+ Dyslipidemia & & $2(1,8)$ \\
\hline & HIV+ Cardiopathy & & $1(0,9)$ \\
\hline & DM+ High Blood Pressure & & $4(3,5)$ \\
\hline
\end{tabular}

SD: standard deviation; min: minimum value; max: maximum value. RA: rheumatoid arthritis; EA: ankylosing spondylitis; A. PSO: psoriatic arthritis; STI: Sexually transmitted infection; DM: Diabetes mellitus; HIV: human immunodeficiency virus. Source: Own elaboration.

\section{Molecular examination}

Comparision of the prevalence of low and high-risk HPV between users and non-users of immunobiologicals are shown in Figure 1. 
Figure 1. Comparision of the prevalence of low and high-risk HPV between users and non-users of immunobiologicals. Presidente Prudente, 2020.

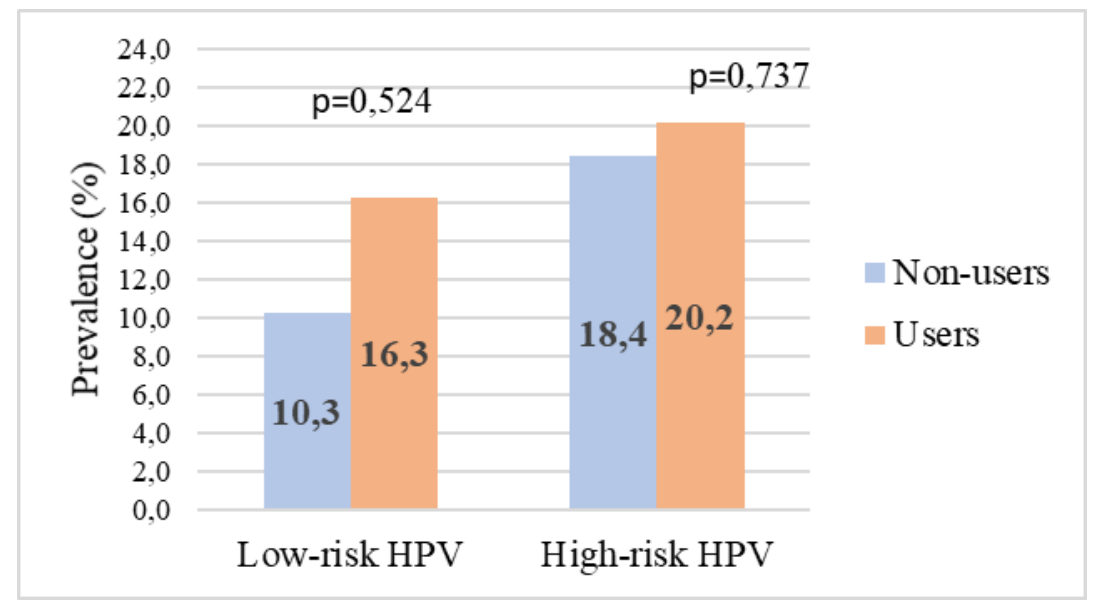

Source: own elaboration.

\section{Low-risk HPV}

A sub-sample of 78 cases from the total study sample (users and non-users) was evaluated for the presence of low-risk HPV, finding a prevalence of $14.1 \%$ (11 cases), with 10 cases in men $(32.3 \%)$ and 1 in women $(2.1 \%)(p<0.001)$. This prevalence increased according to the number of sexual partners $(\mathrm{p}=0.025)$. The types found were HPV 6, 11, 40, 42 and 44, with HPV 42 and 44 being associated with 7 cases (63.6\%); however, the difference was not significant.

When comparing the prevalence of low-risk HPV between the user and non-user groups, prevalence rates of $16.3 \%(8$ cases) and $10.3 \%$ (3 cases) were obtained, respectively ( $\mathrm{p}=0.524)$. Among the 8 positive users, $3(17.6 \%)$ were treated with adalimumab, $2(20 \%)$ with ustekinumab and $3(16.7 \%)$ with secukinumab $(\mathrm{p}=0.999)$, and all of them had psoriatic disease $(\mathrm{p}=0.581)$.

\section{High-risk HPV}

In the total study sample (users and non-users), the prevalence of high-risk HPV was $19.3 \%$ (44 cases). High-risk HPV-positive patients were, on average, 41.1 years old, younger than those who were PCR negative (48.6 years) ( $\mathrm{p}=0.002)$. Of these patients, 23 were users of immunobiologicals, with $11(23.4 \%)$ using adalimumab, 5 (20.8\%) using ustekinumab and 7 (20\%) using secukinumab ( $\mathrm{p}=0.908) ; 20$ of them $(21.7 \%)$ had psoriasis $(\mathrm{p}=0.558)$. According to HPV positivity and typing, the average age of patients with HPV 16 infection was 28.7 years, younger than that of those not infected with this type, which was 47.4 years $(p=0.030)$, an association that was not observed in analyses of HPV 18 or non-16/18 infections. None of the other factors studied were associated with infection by any type of HPV.

Comparing immunobiological users and non-users, the prevalence of high-risk HPV was $20.2 \%$ versus $18.4 \%$, respectively ( $\mathrm{p}=0.737)$. High-risk HPV non-16/18 was the most prevalent type, found in 18 patients $(50 \%)$ in each group $(\mathrm{p}=0.999)$. Younger patients (18 to 50 years old) had a higher prevalence of these subtypes than those over 50 years old $(\mathrm{p}=0.033)$. Among positive users with HPV non-16/18 infection, $8(17 \%)$ were treated with adalimumab, 5 (20.8\%) with ustekinumab and $5(14.3 \%)$ with secukinumab $(\mathrm{p}=0.952)$, and $15(16.3 \%)$ had psoriasis ( $\mathrm{p}=0.861)$. The prevalence and distribution of high-risk HPV subtypes, according to their immunobiological use status, are shown in Figure 2. 
Figure 2. Prevalence and distribution of high-risk HPV subtypes, according to groups using or not using immunobiologicals. Presidente Prudente, 2020.

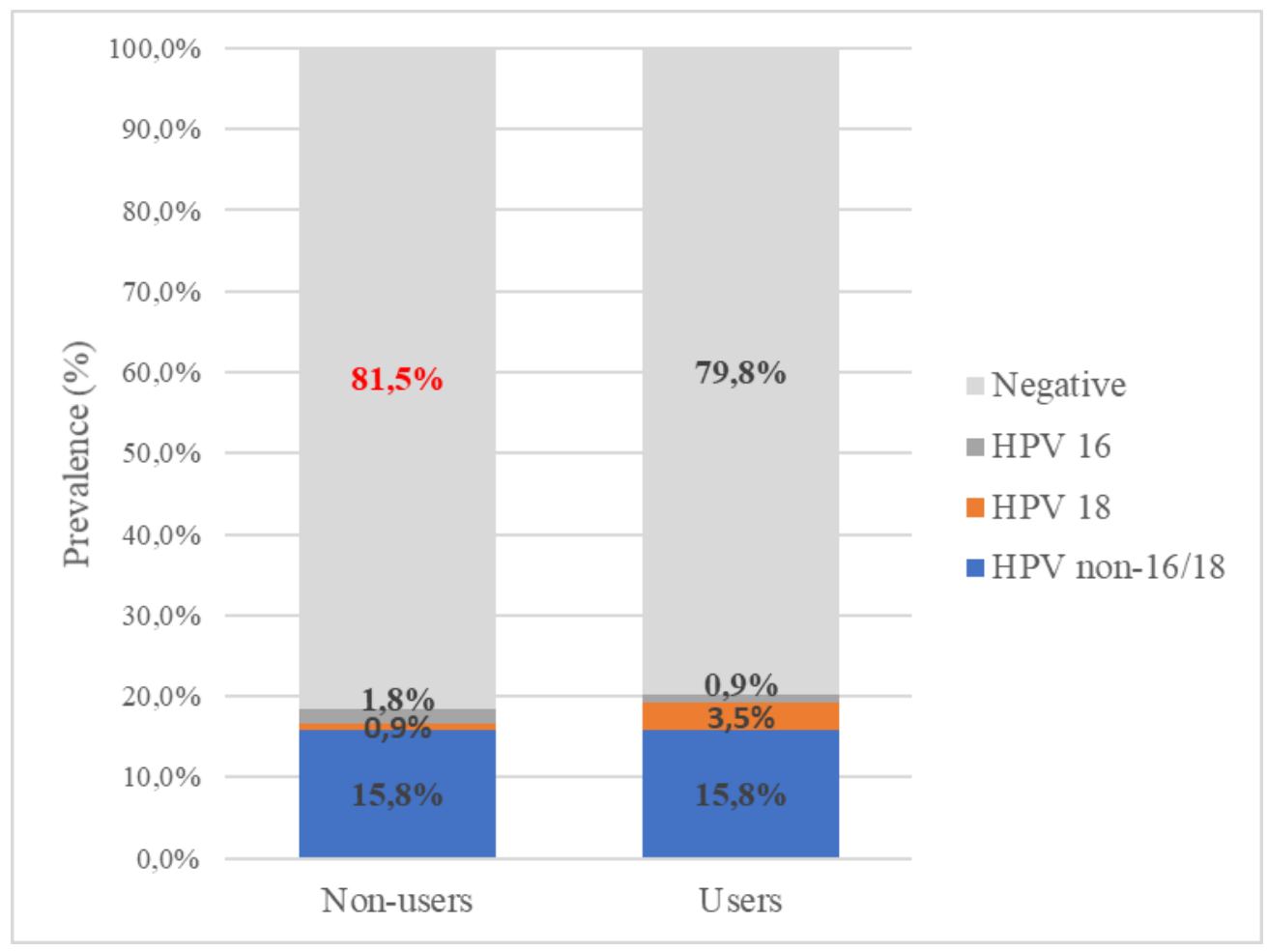

Source: Own elaboration.

It was observed that the distributions of the variables sex and age were different between immunobiologicals users and non-users. Using the PSM method, these variables were paired, and thus, the effect of medication use was evaluated without the effect of confounding variables, forming 62 pairs of homogeneous data.

For the general paired sample, the prevalence of high-risk HPV was 16.9\%. Comparing immunobiological users and non-users, the prevalence of high-risk HPV was $21.0 \%$ and $12.9 \%$, respectively ( $\mathrm{p}=0.231$ ) (Table 3 ). When separated by class of immunobiologicals, the prevalence of high-risk HPV among anti-TNF- $\alpha$ users was $20.0 \%$ and that among anti-IL users was $21.6 \%(\mathrm{p}=0.482)$.

Table 3. Comparison between the groups, users or not users of immunobiologicals, and the prevalence of high-risk HPV after pairing, using Propensity Score Matching. Presidente Prudente, SP, 2020.

\begin{tabular}{|c|c|c|c|c|c|c|}
\hline \multirow[b]{2}{*}{ Factors } & \multicolumn{2}{|c|}{ High-risk-HPV } & Total & \multirow[b]{2}{*}{$\mathbf{p}^{1}$ value } & \multirow[b]{2}{*}{ OR (CG95\%) } & \multirow[b]{2}{*}{$p^{2}$ value } \\
\hline & $\begin{array}{c}\text { Negative } \\
\mathbf{n}=\mathbf{1 0 3} \\
\mathrm{n}(\%)\end{array}$ & $\begin{array}{c}\text { Positive } \\
\mathbf{n}=\mathbf{2 1} \\
\text { n }(\%)\end{array}$ & $\begin{array}{c}\mathbf{n}=\mathbf{1 2 4} \\
\mathrm{n}(\%)\end{array}$ & & & \\
\hline Use of biological medicine & & & & 0,231 & & 0,235 \\
\hline No & $54(87,1)$ & $8(12,9)$ & 62 & & 1 & \\
\hline Yes & $49(79,0)$ & $13(21,0)$ & 62 & & $1,79(0,68-4,69)$ & \\
\hline Use of biological medicine & & & & 0,482 & & \\
\hline Not using & $54(87,1)$ & $8(12,9)$ & 62 & & 1 & \\
\hline Anti-TNF- $\alpha$ & $20(80,0)$ & $5(20,0)$ & 25 & & $1,69(0,49-5,77)$ & 0,404 \\
\hline Anti-IL & $29(78,4)$ & $8(21,6)$ & 37 & & $1,86(0,63-5,48)$ & 0,259 \\
\hline
\end{tabular}

OR: odds ratio; 95\% CG: 95\% confidence gap. ${ }^{1}$ Pearson's chi-square test; ${ }^{2}$ Logistic regression not adjusted. Anti-TNF- $\alpha$ (anti tumor necrosis factor alpha); Anti-IL (anti-interleukins). Source: Own elaboration. 


\section{Discussion}

This study evaluated, by PCR, mucocutaneous smears of the anogenital region, in which HPV can cause benign or malignant warts (Clifford et al., 2005; de Sanjosé et al., 2007; Dommasch et al., 2011; Forman et al., 2012; Parkin et al., 2005), of individuals with psoriasis, inflammatory bowel disease (IBD) or rheumatological diseases using distinct immunobiological classes, unlike the majority of studies that evaluated only users of anti-TNF- $\alpha$ therapies (Bellaud et al., 2014; Handisurya et al., 2016; Kane et al., 2008; Marehbian et al., 2009; Singh et al., 2009) for HPV presence in the uterine cervix (Kane et al., 2008; Marehbian et al., 2009; Singh et al., 2009; Waisberg et al., 2015), eyebrow hair (Bellaud et al., 2014) and skin scraping from the neck (Hsien-Yi \& Tsen-Fang, 2016).

In contrast to the known increased susceptibility to infections with immunobiological (Galloway et al., 2011) use, the knowledge about the risk of anogenital HPV infection is limited and controversial (Antoniou et al., 2008; Kim \& Solomom, 2010). As HPV predisposes patients to malignancies (Bao et al., 2008) and can be underdiagnosed (Fedrizzi, 2011; Oliveira et al., 2013), its detection before the prescription of immunobiologicals is essential (Kane et al., 2008).

Here, HPV positivity in the total study sample was higher in young men, similar to the trend in the general population (Clifford et al., 2005; Fedrizzi, 2011; Oliveira et al., 2013). In immunobiological users, a history of previous viral warts was more frequent, which could be attributed to the predominance of patients with extensive psoriasis in this group (80\%), as these patients had skin barrier dysfunction favouring the penetration of HPV. Handisurya et al. (2016), also found greater positivity for high-risk HPV in patients with psoriasis (Handisurya et al., 2016). As psoriasis is predominant among white people, who made up the majority of our study sample, we did not find a plausible reason for finding a larger number of black people among users of immunobiologicals.

There are reports of the appearance of anogenital warts after anti-TNF- $\alpha$ therapy initiation (Antoniou et al., 2008; Georgala et al., 2012), but few authors have associated HPV infection with isolated immunobiological therapy (Georgala et al., 2012), since many patients with immune-mediated chronic inflammatory diseases use more than one immunosuppressive drug simultaneously (Waisberg et al., 2015).

Combined use of immunosuppressants, including immunobiologicals, prednisone and methotrexate, for prolonged periods contributes to increased infection or reactivation of HPV (Kane et al., 2008; Marehbian et al., 2009) and even to carcinogenesis (Bao et al., 2008). In this study, methotrexate was the drug most associated with immunobiologicals, but it was not possible to determine a cause-effect relationship. Furthermore, if HPV positivity was induced by the immunobiological agent, it was not possible to determine if the infection was acquired after immunobiological use or if there was reactivation of an latent infection (Marehbian et al., 2009).

On the other hand, as observed here, in another study evaluating women with rheumatoid arthritis, there was no increase in the prevalence of HPV in the uterine cervix 6 months after starting treatment with anti-TNF- $\alpha$ therapy compared to healthy individuals (Waisberg et al., 2015). The same occurred in a longer study, which evaluated the anogenital region of patients with psoriasis or IBD receiving TNF- $\alpha$ blockers in comparation to controls with the same diseases (Handisurya et al., 2016). In the same way, in eyebrow hair plucked of psoriatic patients treated with anti-TNF- $\alpha$ therapy, the prevalence of this infection was similar to individuals receiving methotrexate or no systemic therapy (Bellaud et al., 2014).

In this study there was no statistically significant difference in HPV positivity between anti-TNF- $\alpha$ and anti-IL users, or when the patients were compared with people not using immunobiologicals. Anti-IL agents seem to be safer in relation to the triggering or reactivation of infections (Koç et al., 2008; You et al., 2018). Secukinumab was associated with a decrease in HPV infection rates (Brunet-Possenti et al., 2018; Hsien-Yi \& Tsen-Fang, 2016), evolving to PCR negativity after a short time of use, which suggests it plays a protective role against viral persistence (Brunet-Possenti et al., 2018). Additionally, very rare cases of HPV viral warts have been described in association with the use of ustekinumab (Anderson et al., 2018). 
When users and non-users were paired by sex and age, the positivity of high-risk HPV varied little compared to that observed with the total study sample and was not influenced by the type of immunobiological, which confirmed that the prevalence of HPV does not change due to immunobiological use.

A recent study showed that exposure to chronic inflammation induced by TNF- $\alpha$ contributes to the persistence of HPV-infected keratinocytes and their transformation into immortalized cells with greater mutagenic potential. It has been suggested that HPV alone is insufficient for oncogenic conversion and that TNF- $\alpha$ acts as a cofactor for this transformation (Hong et al., 2020). Therefore, it is assumed that blockade of TNF- $\alpha$ with immunobiologicals can play a protective role against malignancies involving HPV.

The limitations of this study include the sample calculation, which considered prevalence data from the general population; the fact that patients in both groups were examined simultaneously, resulting in a total heterogeneous sample before pairing; and that only a sub-sample was screened for low-risk HPV. In addition, the number of users in each sub-group determined by disease and type of immunobiological evaluated was small for determining precise associations between HPV positivity and immunobiologicals use.

A recent study showed that exposure to chronic inflammation induced by TNF- $\alpha$ contributes to the persistence of HPV-infected keratinocytes and their transformation into immortalized cells with greater mutagenic potential. It has been suggested that HPV alone is insufficient for oncogenic conversion and that TNF- $\alpha$ acts as a cofactor for this transformation (Hong et al., 2020). Therefore, it is assumed that blockade of TNF- $\alpha$ with immunobiologicals can play a protective role against malignancies involving HPV.

The limitations of this study include the sample calculation, which considered prevalence data from the general population; the fact that patients in both groups were examined simultaneously, resulting in a total heterogeneous sample before pairing; and that only a sub-sample was screened for low-risk HPV. In addition, the number of users in each sub-group determined by disease and type of immunobiological evaluated was small for determining precise associations between HPV positivity and immunobiologicals use.

\section{Conclusion}

It is concluded that the prevalence of anogenital HPV infection in patients with chronic immune-mediated inflammatory diseases treated with immunobiologicals is similar to that in patients without immunosuppressive conditions or not using immunosuppressive drugs.

\section{References}

Anderson, M. E., Queen, D., Vance, S. L. \& Geskin, L. J. (2018). Ustekinumab-associated disseminated verrucae. JAAD Case Reports, 4 (10), $1030-1033$.

Antoniou, C., Kosmadaki, M. G., Stratigos, A. J. \& Katsambas, A. D. (2008). Genital HPV lesions and molluscum contagiosum occurring in patients receiving anti-TNF-alpha therapy. Dermatology, 216 (4), 364-365.

Bao, Y. P., Li, N., Smith, J. S., Qiao, Y. L. \& ACCPAB members. (2008). Human papillomavirus type distribution in women from Asia: a meta-analysis. International Journal of Gynecological Cancer, 18 (1), 71-79.

Bellaud, G., Gheit, T., Pugin, A., Prétet, J. L., Tommasino, M., Mougin, C. \& Aubin, F. (2014). Prevalence of human Papillomavirus DNA in eyebrow hairs plucked from patients with psoriasis treated with TNF inhibitors. Journal of the European Academy of Dermatology and Venereology, 28 (12), 1816-1820.

Brunet-Possenti, F., Charpentier, C., Collin, G., Descamps, D. \& Descamps, V. (2018). Impact of anti-interleukin-17 treatment on cutaneous and genital human papillomavírus infection. The British Journal of Dermatology, 179 (5), 1179-1180.

Colpani, V., Falcetta, F. S., Bidinotto, A. B., Kops, N. L., Falavigna, M., Hammes, L. S., Benzaken, A. S., Maranhão, A. G. K., Domingues, C. M. A. S. \& Wendland, E. M. (2020). Prevalence of human papillomavirus (HPV) in Brazil: A systematic review and meta-analysis. PLoS ONE, 15 (2), e229154. 
Dixon, W. G., Hyrich, K. L., Watson, K. D., Lunt, M., Galloway, J., Ustianowski, A., BSRBR Control Centre Consortium, DPM Symmons \& BSR Biologics Register. (2010). Drug-specific risk of tuberculosis in patients with rheumatoid arthritis treated with anti-TNF therapy: results from the British Society of Rheumatology Biologic Register (BSRBR). Annals of the Rheumatic Diseases, 69 (3), 522-528.

Dommasch, E. D., Abuabara, K., Shin, D. B., Nguyen J., Troxel, A. B. \& Gelfand, J. M. (2011). The risk of infection and malignancy with tumor necrosis factor antagonists in adults with psoriatic disease: a systematic review and meta-analysis of randomized controlled trials. Journal of the American Academy of Dermatology, 64 (6), 1035-1050.

Fedrizzi, E. N. (2011). Epidemiologia da infecção genital pelo HPV. Revista Brasileira de Patologia do Trato Genital Inferior, 1(1), 3-8.

Forman, D., Martel, C., Lacey, C. J., Soerjomataram, I., Lortet-Tieulent, J., Bruni, L., Vignat, J., Ferlay, J., Bray, F., Plummer, M. \& Franceschi, S. (2012). Global burden of human papillomavírus and related diseases. Vaccine, 30 (Suppl 5), F12-F13.

Galloway, J. B., Hyrich, K. L., Mercer, L. K., Dixon, W. G., Fu, B., Ustianowski, A. P., Watson, K. D., Lunt, M., Symmons, D. P. M., BSRBR Control Centre Consortium \& British Society for Rheumatology Biologics Register. (2011). Anti-TNF therapy is associated with increased risk of serious infections in patients with rheumatoid arthritis especially in the first 6 months of treatment: updated results from the British Society for Rheumatology Biologics Register with special emphasis on risks in the elderly. Rheumatology, 50 (1), 124-131.

Georgala, S., Katoulis, A. C., Kanelleas, A., Befon, A. \& Georgala, C. (2012). Letter: Human papilloma virus and molluscum contagiosum lesions related to infliximab therapy for psoriasis: a case series. Dermatology Online Journal, 18 (4), 9.

Handisurya, A., Lázár, S., Papay, P., Prismas, C., Haitel, A., Horvat, R., Tanew, A., Vogelsang, H. \& Kirnbauer, R. (2016). Anogenital human papillomavirus prevalence is unaffected by therapeutic tumour necrosis factor-alpha inhibition. Acta Dermato-Venereologica, 96 (4), 494-498.

Hong, H. S., Akhavan, J., Lee, S. H., Kim, R. H., Kang, M. K., Park, N. H. \& Shin, K. H. (2020). Proinflammatory cytokine TNF- $\alpha$ promotes HPV-associated oral carcinogenesis by increasing cancer stemness. International Journal of Oral Science, 12 (1), 3.

Hsien-Yi, C. \& Tsen-Fang, T. (2016). The impact of secukinumab treatment on the prevalence of human papillomavirus in patients with psoriasis: a pilot study. Journal of the American Academy of Dermatology, 75 (1), 224-226.

Kane, S., Khatibi, B. \& Reddy, D. (2008). Higher incidence of abnormal Pap smears in women with inflammatory bowel disease. The American Journal of Gastroenterology, 103 (3), 631-636.

Kim, S. Y. \& Solomom, D. H. (2010). Tumor necrosis fator blockade and the risk of viral infection. Nature Reviews Rheumatology, 6 (3), 165-174.

Koç, E., Tunca, M., Arda, E., Akar, A., Kurumlu, Z. \& Demiriz, M. (2008). Multiple widespread warts due to etanercept treatment in a psoriatic patient: a case report. Journal of the Turkish Academy of Dermatology, 2 (1), 82103c.

Lacey, C. J. (2019). HPV vaccination in HIV infection. Papillomavirus Research, 8, 100174.

Marehbian, J., Arrighi, H. M., Hass, S., Tian, H. \& Sandborn, W. J. (2009). Adverse events associated with common therapy regimens for moderate-to-severe Crohn's disease. The American Journal of Gastroenterology, 104 (10), 2524-2533.

Mota, L. M. H., Cruz, B. A., Brenol, C. V., Pollak, D. F., Pinheiro, G. R. C., Laurindo, I. M. M., Pereira, I. A., de Carvalho, J. F., Bertolo, M. B., Pinheiro, M. M., Freitas, M. V. C., da Silva, N. A., Louzada-Júnior, P., Sampaio-Barros, P. D., Giorgi, R. D. N., Lima, R. A. C. \& Andrade, L. E. C. (2015). Segurança do uso de terapias biológicas para o tratamento de artrite reumatoide e espondiloartrites. Revista Brasileira de Reumatologia, 55 (3), 281-309.

Oliveira, G. R., Vieira, V. C., Barral, M. F. M., Dowich, V., Soares, M. A., Conçalves, C. V. \& Martinez, A. M. B. (2013). Risk factors and prevalence of HPV infection in patients from Basic Health Units of an University Hospital in southern Brazil. Revista Brasileira de Ginecologia e Obstetrícia, 35 (5), 226232.

Parkin, D. M., Bray, F., Ferlay, J. \& Pisani, P. (2005). Global cancer statistics, 2002. CA: A Cancer Journal for Clinicians, 55 (2), 74-108.

Sanjosé, S., Brotons, M. \& Pavón, M. A. (2018). The natural history of human papillomavirus infection, Best Practice \& Research Clinical Obstetrics \& Gynaecology, 47, 2-13.

Serrano, B., Brotons, M., Bosch, F. X. \& Bruni, L. (2018). Epidemiology and burden of HPV-related disease. Best Practice \& Research Clinical Obstetrics \& Gynaecology, 47, 14-26.

Singh, H., Demers, A. A., Nugent, Z., Mahmud, S. M., Kliewer, E. V. \& Bernstein, C. N. (2009). Risk of cervical abnormalities in women with inflammatory bowel disease: a population-based nested case-control study. Gastroenterology, 136 (2), 451-458.

Singh, J. A., Wells, G. A., Christensen, R., Ghogomu, E. T., Maxwell, L. J., MacDonald, J. K., Filippini, G., Skoetz, N., Francis, D., Lopes, L. C., Guyatt, G. H., Schmitt, J., La Mantia, L., Weberschock, T., Roos, J. F., Siebert, H., Hershan, S., Lunn, M. P., Tugwell, P. \& Buchbinder, R. (2011). Adverse effects of biologics: a network meta-analysis and Cochrane overview. Cochrane Database of Systematic Reviews, 2011 (2), CD008794.

Waisberg, M. G., Ribeiro, A. C. M., Candido, W. M., Medeiros, P. B., Matsuzaki, C. N., Beldi, M. C., Tacla, M., Caiaffa-Filho, H. H., Bonfa, E. \& Silva, C. A. (2015). Human papillomavirus and chlamydia trachomatis infections in rheumatoid arthritis under anti-TNF therapy: an observational study. Rheumatology International, 35 (3), 459-463.

Yiu, Z. Z. N., Smith, C. H., Ashcroft, D. M., Lunt, M., Walton, S., Murphy, R., Reynolds, N. J., Ormerod, A. D., Griffiths, C. E. M., Warren, R. B. \& BADBIR Study Group. (2018). Risk of serious infection in patients with psoriasis receiving biologic therapies: a prospective cohort study from the British Association of Dermatologists Biologic Interventions Register (B ADBIR). The Journal of Investigative Dermatology, 138 (3), 534-541. 